\title{
Construction and characterization of a high-quality cDNA library of Cymbidium faberi suitable for yeast one- and two- hybrid assays
}

Yanqin $X u^{1}$, Junjiang Zhou ${ }^{2,3}$, Qingqing Liu, ${ }^{2,3}$, Kunpeng Li ${ }^{4}$ and Yin Zhou ${ }^{2,3^{*}}$ (D)

\begin{abstract}
Background: Cymbidium faberi is one of the oldest cultivars of oriental orchids, with an elegant flower fragrance. In order to investigate the molecular mechanism and the functions of related proteins in the methyl jasmonate (MeJA) signaling pathway, one of the main components of flower fragrance in C. faberi, yeast one- and two-hybrid three-frame cDNA libraries were constructed.

Results: In this study, a modified cDNA library used for yeast one- and two-hybrid screening was successfully constructed, with a recombinant efficiency of 95\%. The lengths of inserted fragments ranged from 750 3000 bp, and the library capacity reached $6 \times 10^{9} \mathrm{CFU} / \mu \mathrm{g}$ of cDNA insert, which was suitable for the requirements of subsequent screening. Finally, a homologous protein related with pathogenesis was screened out by the bait vector of $\mathrm{CfbHLH36,} \mathrm{which} \mathrm{may} \mathrm{participate} \mathrm{in} \mathrm{the} \mathrm{MeJA} \mathrm{signaling} \mathrm{pathway.}$

Conclusion: The yeast one- and two-hybrid library of $C$. faberi provides large amounts of useful information for the functional genomics research in C. faberi, and this method could also be applied to other plants to screen DNAprotein and protein-protein interactions.
\end{abstract}

Keywords: Yeast two hybrid, Yeast one hybrid, Three-frame cDNA library, Normalization, Cymbidium faberi

\section{Background}

Orchidaceae is one of the largest families of monocotyledonous plants. In cultivation, orchids are generally divided into tropical and oriental cultivars. Cymbidium faberi is famous for its soft color and strong flower fragrance. However, the wild populations have significantly deteriorated due to over-exploitation. In order to develop new cultivars of Cymbidium via genetic engineering and preserve the wild resources, it is imperative to elucidate the biosynthetic pathways and molecular mechanisms of its economically important traits.

The yeast one- and two-hybrid systems are commonly used to screen for interactions between target proteins

\footnotetext{
* Correspondence: ripplet0931@hotmail.com

${ }^{2}$ Center of Applied Biotechnology, Wuhan University of Bioengineering,

Wuhan 430415, People's Republic of China

${ }^{3}$ College of Bioscience and Biotechnology, Wuhan University of

Bioengineering, Wuhan 430415, People's Republic of China

Full list of author information is available at the end of the article
}

and bait molecules. The yeast one-hybrid system is generally used to analyze DNA-protein interactions, while the yeast two-hybrid system can be used to analyze protein-protein interactions based on the expression of the reporter genes, and both are widely used in functional genomics studies [1]. In general, the yeast twohybrid system requires a high-quality cDNA library. By contrast, there are two ways to construct a yeast onehybrid library, the protein-centered approach and the DNA-centered approach. The former method requires a random short DNA sequence insertion library and the protein as the bait. The latter method requires a cDNA library and a cis-element as the bait [2]. Therefore, the cDNA library of the two-hybrid system can also be extended to yeast one-hybrid screening.

Based on the high-throughput screening and stringent screening pressure, many researches have obtained candidate prey proteins by yeast one- and two-hybrid

(c) The Author(s). 2020 Open Access This article is distributed under the terms of the Creative Commons Attribution 4.0 International License (http://creativecommons.org/licenses/by/4.0/), which permits unrestricted use, distribution, and reproduction in any medium, provided you give appropriate credit to the original author(s) and the source, provide a link to the Creative Commons license, and indicate if changes were made. The Creative Commons Public Domain Dedication waiver (http://creativecommons.org/publicdomain/zero/1.0/) applies to the data made available in this article, unless otherwise stated. 
assays, like in wheat [3, 4], Arabidopsis [5], rice [6], populus [7], kiwifruit [8] and so on. Moreover, increasing numbers of studies focused on improving the screening efficiency, saving time and decreasing the cost required to identify target molecules in yeast one- and two-hybrid system assays [9, 10].

Functional genomics based on transcriptomic profiling of the expression of different genes in different flowering stages was used to screen target proteins involved in the flower development of C. faberi [11]. Methyl jasmonate (MeJA) has been extensively explored as a volatile compound and a signal molecule to interact with other organisms (plants, animals and microbes) $[12,13]$. The biosynthetic pathway of MeJA has been elaborated in model plants and its complicated regulation mechanism was continuously investigated [14]. Many transcription factors were demonstrated to be positive or negative regulators in MeJA metabolism, especially MYC gene family, like MYCs and JAASSOCIATED MYC2-LIKE (JAMs) [15], which could antagonistically regulate the downstream genes in MeJA signaling pathway.

In this study, we first constructed a cDNA library of $C$. faberi including almost all of the expressed genes in different tissues and different flowering stages, which extended the range of the subsequent screening of target proteins. Additionally, a yeast library was constructed and used for yeast hybrid assay, enabling the easy and fast screening of target proteins via bidirectional screening. The lengths of inserted fragments in the library ranged from $750 \sim 3000 \mathrm{bp}, 65 \%$ of which were longer than $1500 \mathrm{bp}$. Due to the lack of genomic sequences of C. faberi, it is imperative to construct a high-quality yeast library for the further point-to-point verification and functional identification of target proteins. The longer the fragments, the more convenient it is to detect the exact functions of the integral target proteins.

A bHLH transcription factor, CfbHLH36, was screened by RNA-seq results and blasted with AtJAM3 which is a negative regulator in MeJA signaling pathway in Arabidopsis [16]. Therefore, we would like to excavate the target interaction proteins and regulation mechanism of CfbHLH36 in C. faberi. A candidate protein homologous to a protein involved in pathogenesis was screened out by yeast two-hybrid assay with the constructed yeast library, suggesting that this library is suitable for searching unknown proteins with the bait proteins from C. faberi.

\section{Results}

Extraction of total RNA from different tissues and flowering stages of $C$. faberi

Leaves, roots, flower buds, blooming flowers and withered flowers of C. faberi were collected for total

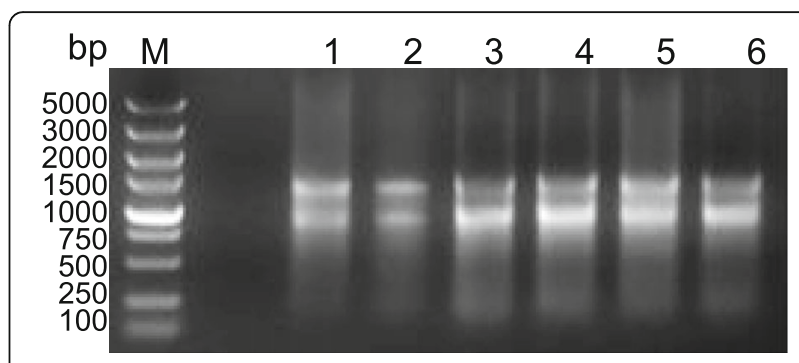

Fig. 1 Total RNA extracted from flowers, leaves and roots of $C$. faberi. M: DL 5000 DNA Marker; 1: flowers in the bud stage; 2: flowers in the blooming stage; 3 : flowers in the withered stage; 4 and 5 : young leaves; 6: roots

RNA extraction. The quality of the total RNA samples is shown in Fig. 1, which obviously shows the bands corresponding to the intact $28 \mathrm{~S}$ and $18 \mathrm{~S}$ rRNA. The total RNAs had an A260/A280 ratio of $\sim 2.0$ and a concentration of $1.3 \sim 2.4 \mu \mathrm{g} / \mu \mathrm{L}$, which fulfilled the requirements for library construction.

\section{The mRNA was purified and reverse-transcribed into double-stranded CDNA, which was then normalized to harvest confluent ds CDNA}

As shown in Fig. 2a, the mRNA was purified from total RNA by adsorption to magnetic beads. The length of the extracted mRNAs ranged from 100 to $3000 \mathrm{bp}$. The mRNA was then reverse-transcribed into first-strand cDNA, which was used to synthesize the double-stranded cDNA by LD-PCR (Fig. 2b). The cDNA fragments ranged in size from 300 to $2000 \mathrm{bp}$. The ds cDNA was subsequently purified using a CHROMA SPIN TE-400 column as shown in Fig. 2c. The normalization showed that ds cDNAs were uniformly dispersed, without the disproportionate enrichment of specific fragments. Furthermore, the range of lengths was similar to that of the preceding non-normalized ds cDNA, except for the loss of short fragments smaller than $300 \mathrm{bp}$ (Fig. 2d).

\section{The yeast one- and two-hybrid library was successfully constructed with a large library capacity and appropriate inserted fragments}

Homologous recombination was used to ligate the cDNAs into the pGADT7-SmaI vector to construct the threeframe cDNA library. After condensation and purification, the recombinant vectors were electroporated into competent cells of $E$. coli DH10B. The lengths of the inserted fragments ranged from $750 \mathrm{bp}$ to $3000 \mathrm{bp}$, with a recombination efficiency of $95 \%$ (Fig. 3a). The transformed bacteria were diluted for plate counting and the result showed that the bacteria library was $1.58 \times 10^{9} \mathrm{CFU} / \mathrm{mL}$ (Fig. 3b). Eight of the 19 positive colonies were sequenced and blasted in NCBI database, and all of them were homologous to the corresponding proteins in other 


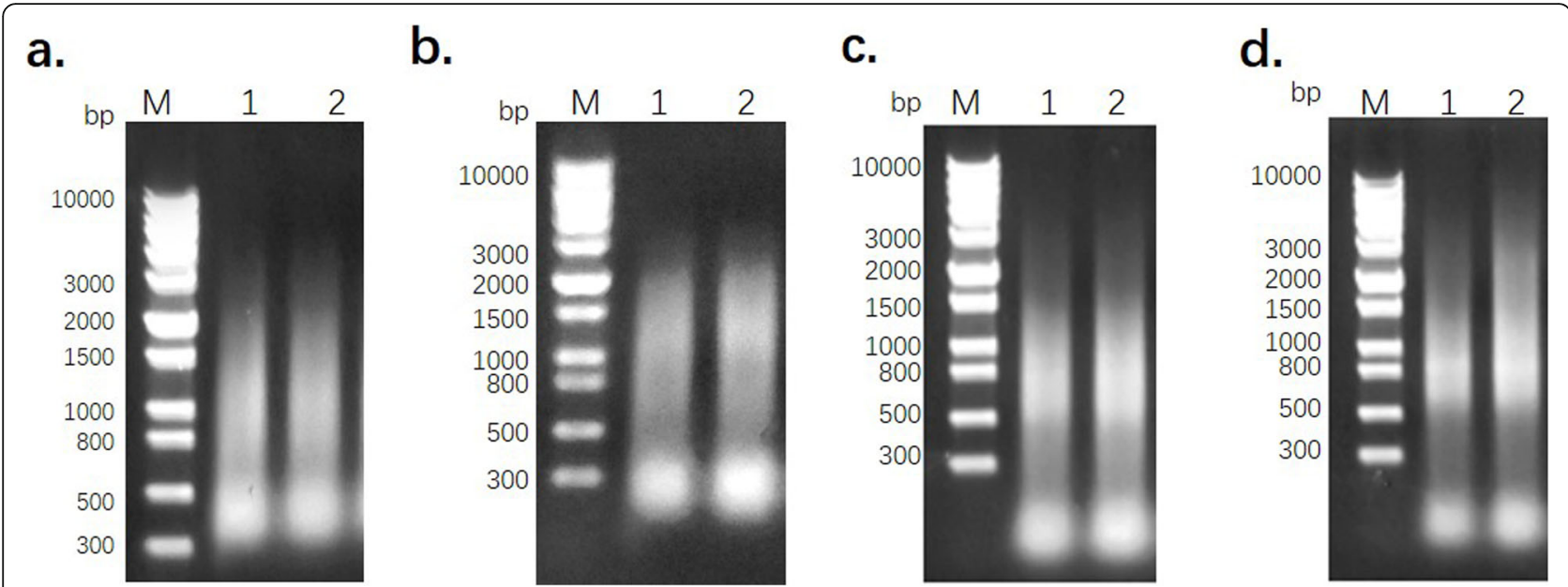

Fig. 2 The synthesis, purification and normalization of CDNA. a. the purification of mRNA from total RNA; $\mathbf{b}$. the double-strand cDNA synthesized by LD-PCR; $\mathbf{c}$. the purification of CDNA using a CHROMA SPIN TE-400 column; $\mathbf{d}$. the normalization of the ds CDNA. M: DL 10000 DNA Marker; 1 : mRNA or CDNA from C. faberi; 2: positive control

Orchidacea plants including Phalaenopsis equestris (XP 020598791.1, XP_020578536.1, XP_020573601.1, XP_ 020578326.1, XP_020579629.1), Dendrobium catenatum (XP_020688313.1) and Cymbidium hybrid cultivar (AAA19578.1) (Additional file 1). The library plasmid was then transformed into S. cerevisiae Y187 to obtain the yeast library, and the diluted yeast cells were grown on the YPDA plates. The counting result showed that the yeast library capacity was $1.2 \times 10^{8} \mathrm{CFU} / \mathrm{mL} \times 50$ $\mathrm{mL}=6 \times 10^{9} \mathrm{CFU} / \mu \mathrm{g}$ of cDNA insert (Fig. 3c).

a.

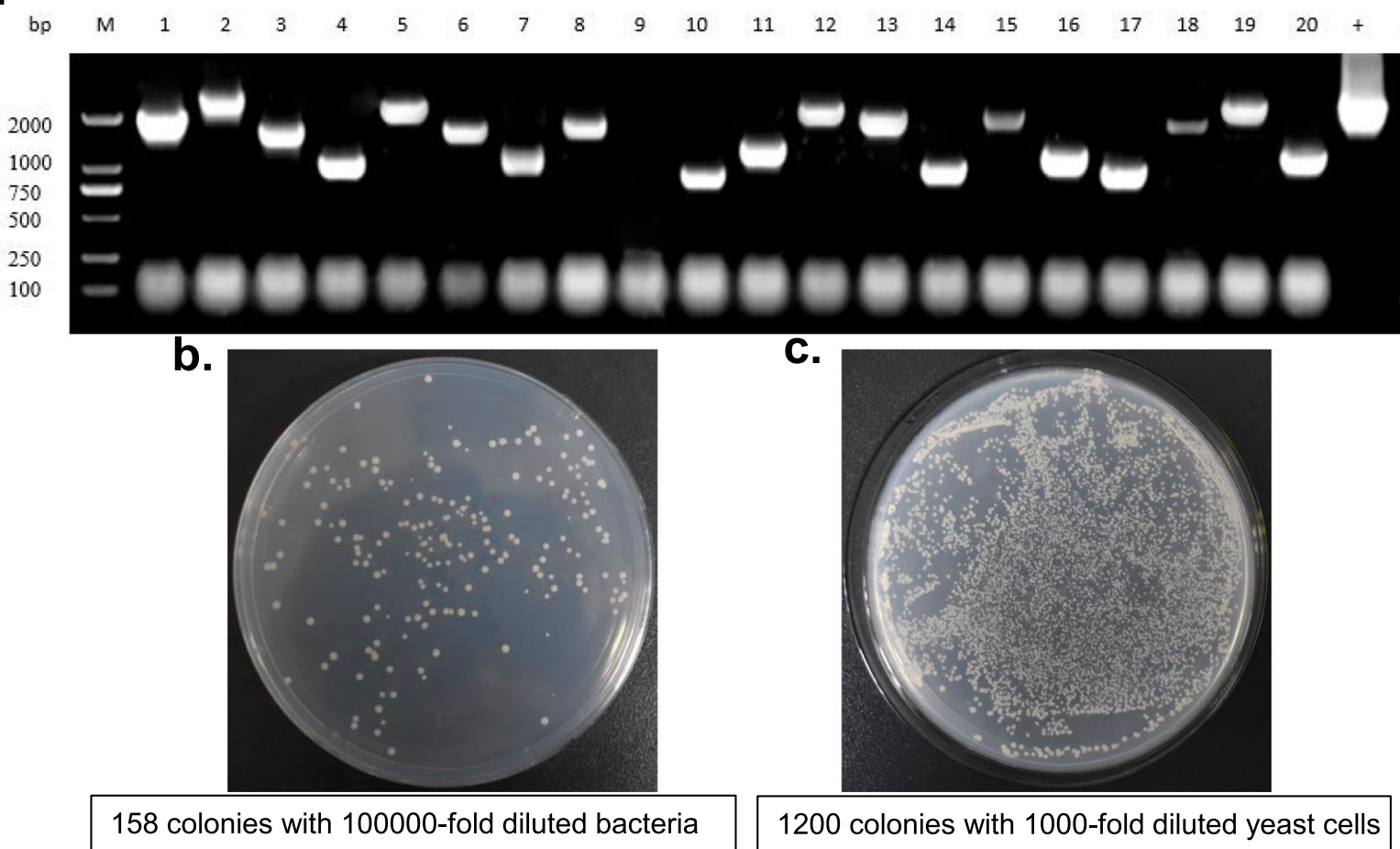

Fig. 3 The quantification of the library by sequencing of positive colonies and plate counting. a. agarose gel electrophoresis of PCR products from randomly selected 20 colonies. M: DL 2000 DNA Marker; 1-20: PCR products of 20 colonies; +: pGADT7-T vector as positive control; -: ddH $\mathrm{H}_{2} \mathrm{O}$ as negative control. b. plate counting of 100,000-fold diluted bacteria from the E. coli library. c. plate counting of 1000-fold diluted yeast cells from the yeast library 
One candidate gene related with pathogenesis was screened out from yeast library and might participate in MeJA-mediated biotic stress responses

CfbHLH36 transcription factor related with the MeJA signaling pathway in $C$. faberi was selected to construct bait vector for library screening. The recombinant plasmid of pGBKT7-CfbHLH36 could be grown on SD/-Leu/-Trp plates with prey vector of pGADT7, suggesting that the recombinant plasmid could be successfully transformed into the host cells with no toxicity. But its growth on SD/ -Leu/-Trp/-His plates showed that the recombinant plasmid could autoactivate the expression of His reporter gene, which could be inhibited by $10 \mathrm{mM}$ 3' AT (Fig. 4). The subsequent screening plates would observe this growth condition. As shown in Fig. 5a, as the bait vector and the Y187 yeast library grown into a typical clover-leaf shape, the yeast zygotes were cultured onto the $\mathrm{SD} /-\mathrm{Leu} /$ -Trp/-His/X- $\alpha$-Gal plates with $10 \mathrm{mM}$ 3'AT for selection. Then the positive colonies were grown in blue for the $L a c Z$ reporter gene could catalyze the $\mathrm{X}-\alpha-\mathrm{Gal}$ supplemented in the media.

About 50 blue colonies were grown in stringent QDO plates (Fig. 5b), of which 36 colonies were identified by PCR and sequencing. As shown in Fig. $5 \mathrm{c}$, the inserted fragments were ranged from $500 \sim 2000 \mathrm{bp}$ in length via electrophoresis. The positive colonies were sequenced and blasted in NCBI database. Among them, one of the proteins homologous to a pathogenesis-related protein derived from Phalaenopsis equestris (XP_020589637.1) was screened out (Additional file 2).

\section{Discussion}

In this study, we constructed a high-quality cDNA library that can be used for both yeast one- and two- hybrid assays, which provides a solid foundation for functional identification of unknown proteins in $C$. faberi. The final product of gene expression often interacts with other proteins or DNAs to form a complex, resulting complicated regulation of gene expression that enables organisms to survive in different environments. The high-throughput screening of interactions between target proteins and a bait vector enables the fast and efficient identification of links in the complicated and elegant regulation networks of gene expression found in higher organisms.

In order to improve the efficiency of transferring cDNA fragments into multiple destination vectors, several yeast one- and two-hybrid systems have been modified to use Gateway technology, In-Fusion technology and so on [17-19]. Moreover, in recent studies two cDNA libraries were respectively used as bait library and prey library, followed by mating and screening, enabling the screening of multiple libraries in one pool. Examples include BFG-Y2H [20], CrY2H [21], and RLL-Y2H [22]. The continuous improvement of the construction methods makes the information included in the library more comprehensive and more integral.

The crucial elements for the construction of a highquality yeast library include the purity, integrity and concentration of mRNA, the ligation efficiency, and the transformation efficiency. The standards used to judge the quality of a yeast library are mainly based on the recombination efficiency, the lengths of inserted fragments, and the library capacity. In general, a cDNA library that includes the integral expression information must contain at least $1 \times 10^{6} \mathrm{CFU}$ [23]. In this study, the three indexes of the yeast library of C. faberi were $95 \%, 750 \sim 3000 \mathrm{bp}$ and $6 \times 10^{9} \mathrm{CFU} / \mu \mathrm{g}$ of cDNA insert, respectively, which

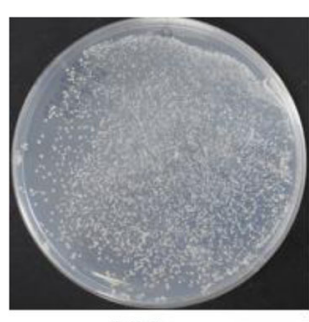

DDO

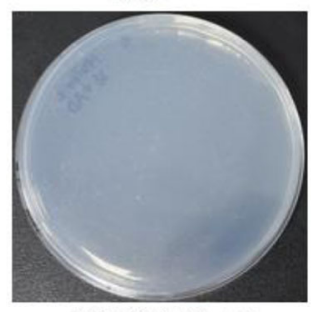

TDO/3AT(10 mM)

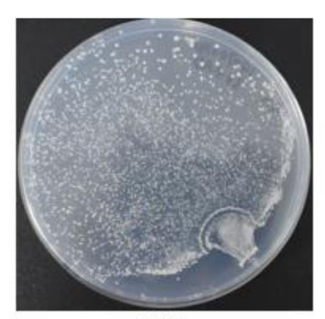

TDO

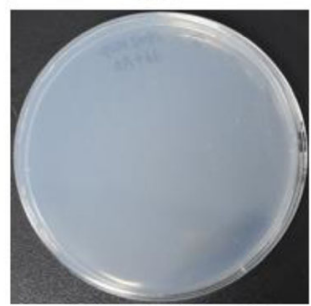

TDO/3AT $(15 \mathrm{mM})$

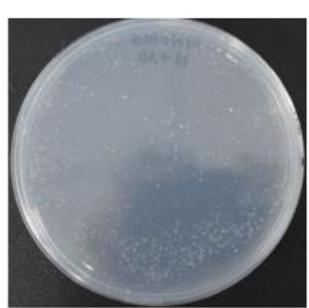

TDO/3AT(5 mM)

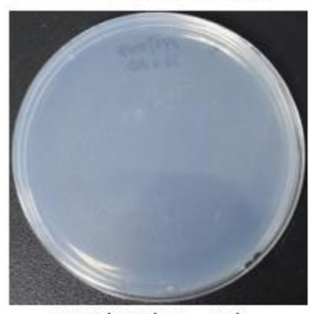

TDO/3AT(20 mM)

Fig. 4 The toxicity and auto-activation detection of pGBKT7-CfbHLH36 bait vector. DDO: SD/-Leu/-Trp culture media; TDO: SD/-Leu/-Trp/-His culture media; TDO/3AT: SD/-Leu/-Trp/-His culture media supplemented with different concentrations of 3-Aminotriazole 
a.

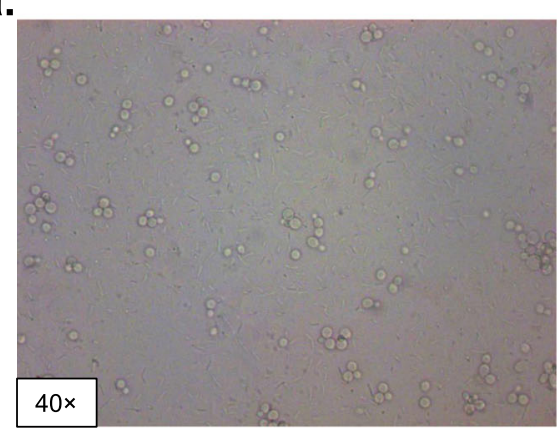

b.

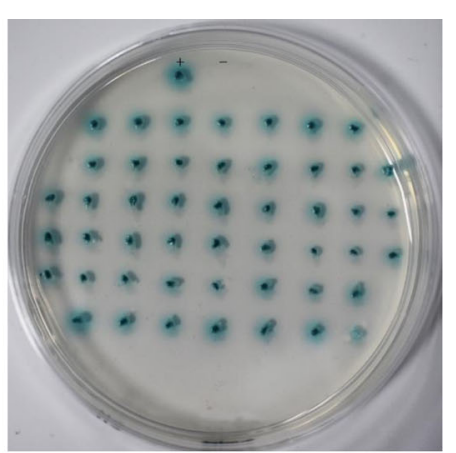

C.

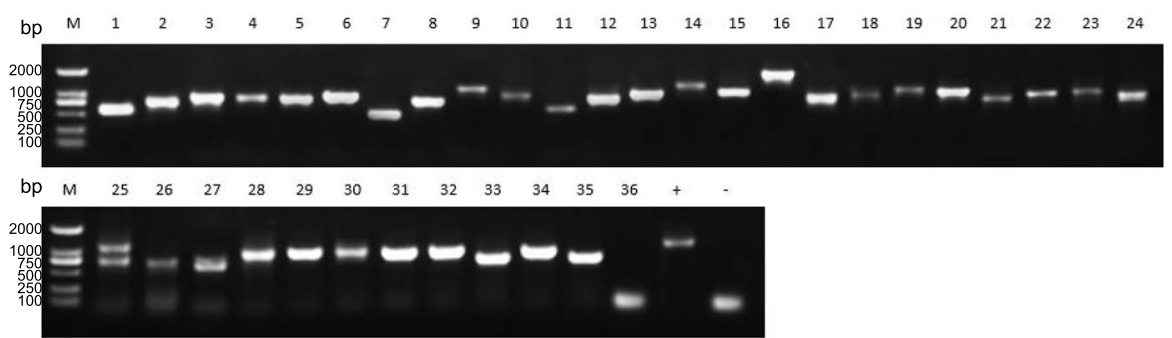

Fig. 5 The screening of the constructed yeast library. a. the diploid yeast cells were grown into a typical clover-leaf shape stage; b. the blue positive colonies were grown in stringent QDO plates to increase the selection pressure. +: pGBKT7-53 and pGADT7-T co-transformed as positive control; -: pGBKT7-Lam and pGADT7-T co-transformed as negative control; c. agarose gel electrophoresis of PCR products from selected positive colonies. +: pGADT7-T vector as positive control; -: $\mathrm{ddH}_{2} \mathrm{O}$ as negative control

fulfilled the requirements of the subsequent screening. The corresponded three indexes of a recently published yeast library of Salvia miltiorrhiza were 100\%, 500 2000 bp and $1.45 \times 10^{6} \mathrm{CFU} / \mathrm{mL}$, respectively [24]. The yeast two-hybrid library from tobacco leaves infected by Lasiodiplodia theobromae had a size of $1.2 \times 10^{8} \mathrm{CFU} / \mathrm{mL}$, with inserted fragments of 350 2000 bp [25].

In order to avoid creating a limited cDNA library due to restricted spatiotemporal expression, in this study the total RNA was extracted from different tissues and different flowering stages, which could enlarge the screening scope, especially for crucial genes related to flower development. Correspondingly, the quantity of the primary RNA used for reverse transcription should be sufficiently large. The cDNA fragments were randomly inserted into the library vector pGADT7, which probably leads to frame-shifts of the expression of the cDNA. In this study three different library vectors, pGADT7SmaI-1, pGADT7-SmaI-2 and pGADT7-SmaI-3, were respectively ligated with the cDNA, which could increase the efficiency of screening out target proteins with the correct encoding frame. This step also required a high quantity and quality of the cDNA. Therefore, it is necessary to prepare a good cDNA library in advance.

Since a yeast two-hybrid system comprises an expressed cDNA library, it is also compatible with yeast one-hybrid screening. In this study, the cDNA library could be used to construct both yeast one- and two-hybrid systems. As shown in Fig. 6, the universal yeast library in this study was constructed based on a large, high-quality cDNA library derived from different tissues and developmental stages of $C$. faberi. The library plasmids could be electroporated into the $\mathrm{Y} 1 \mathrm{H}$ yeast competent cells generated from a colony containing a cis-element-based bait plasmid. The yeast one-hybrid screening was based on the activation of the aureobasidin resistance gene in the pAbAi vector, and positive colonies were selected on plates with a gradient of aureobasidin concentrations [26]. For the yeast two-hybrid assay, the bait vector was electroporated into a sexually compatible haploid yeast strain (Y2H Gold with the "a" mating type), and the yeast library was constructed in the strain Y187 ( $\alpha$ mating type). Consequently, mating could be used to combine the bait and prey constructs in the same diploid yeast cells [9]. The diploid yeast cells displayed a typical clover-leaf shape under the microscope. In this case, the target proteins could be screened out from one library, and sometimes the screening results of $\mathrm{Y} 1 \mathrm{H}$ and $\mathrm{Y} 2 \mathrm{H}$ could be mutually confirmed for the same metabolic pathway.

Methyl jasmonate (MeJA) participates in many processes of plant development, biotic and abiotic responses $[11,27,28]$. In this study, a target protein, homologous to a pathogenesis-related protein in Phalaenopsis equestris (XP_020589637.1) was screened out based on the CfbHLH36 transcription factor as the bait vector. CfbHLH36 transcription factor is involved in the MeJA 


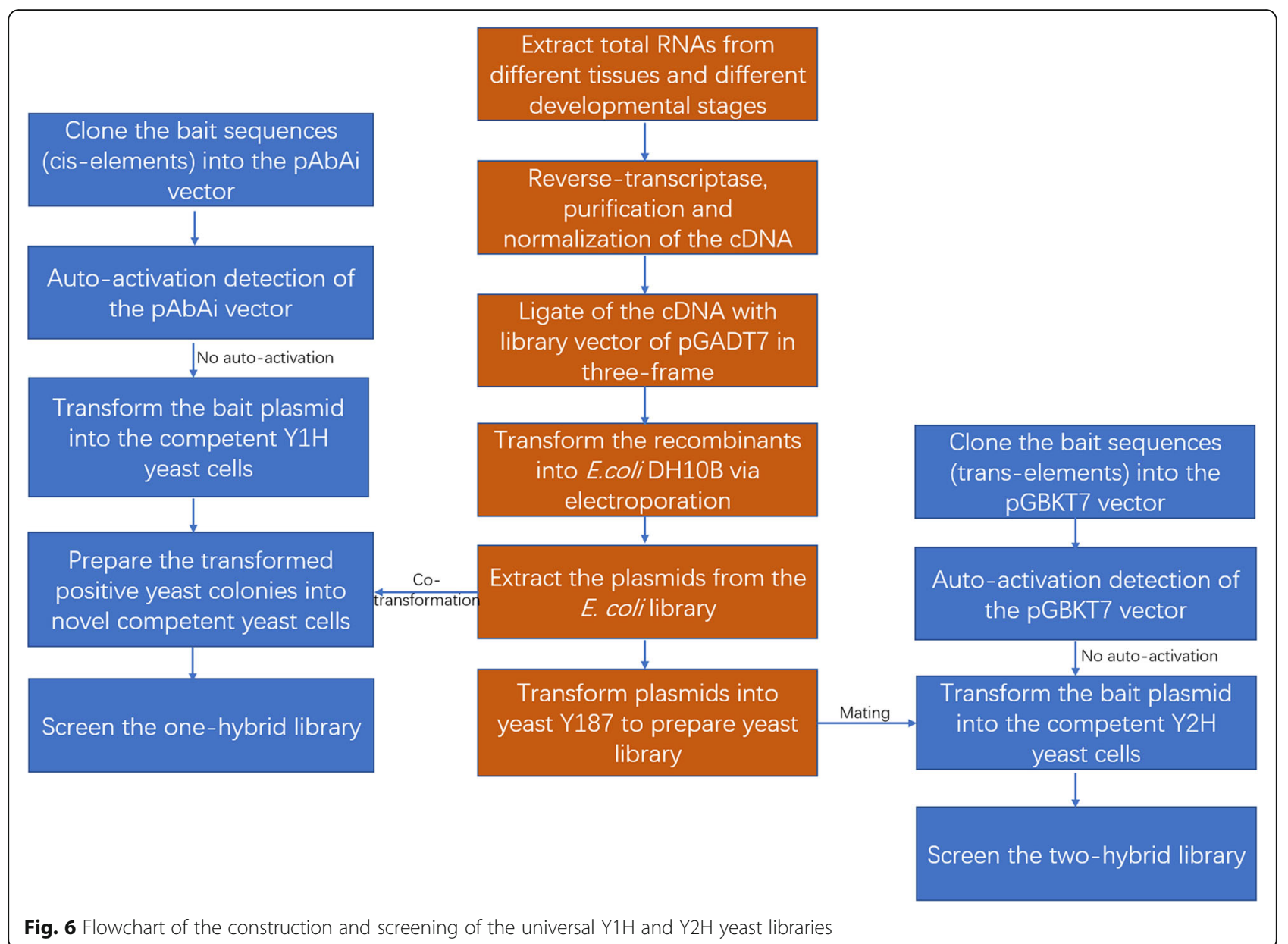

signaling pathway, for it is homologous to AtJAM3 in Arabidopsis and its expression pattern is negatively correlated with the contents of MeJA in different flower development stages of $C$. faberi (unpublished data). As MeJA plays a crucial role in the plant responses to external stimuli [29], we expected that CfbHLH36 transcription factor may participate in the MeJA-mediated interaction between plants and microbes in C. faberi. But the exact function mechanism remained to be explored in the further research.

\section{Conclusion}

A universal three-frame yeast library of C. faberi was successfully constructed, which provides a useful tool for the research on functional genomics of $C$. faberi, especially targeting transcription factors and related proteins in MeJA signaling pathway and flower development.

\section{Methods}

\section{Plant materials}

Plantlets of $C$. faberi were collected from one wild population in Dangyang, Hubei province $\left(30^{\circ} 55^{\prime} 25^{\prime \prime} \mathrm{N}\right.$, $\left.111^{\circ} 51^{\prime} 24^{\prime \prime} \mathrm{E}\right)$, China, which was identified by taxonomist professor Yanqin $\mathrm{Xu}$. They were then transplanted and divided propagated in the greenhouse of Wuhan University of Bioengineering. Herbarium specimens of $C$. faberi were deposited in the herbarium of Jiangxi University of Traditional Chinese Medicine (Y. Zhou \& Y. Q Xu 20,120,301).

\section{Extraction of total RNA from different tissues of $C$. faberi and first-strand CDNA synthesis}

Fresh samples of C. faberi, including young leaves, root, and flowers in different stages (flower bud stage, blooming stage and withered stage) were collected and ground into powder after freezing with liquid nitrogen. The total RNA was extracted according to the Trizol Extraction Protocol (Takara, Dalian, China). The extracted total RNA $(\sim 200 \mu \mathrm{g})$ was diluted in $100 \mu \mathrm{L}$ DEPC $\mathrm{ddH}_{2} \mathrm{O}$, incubated at $65^{\circ} \mathrm{C}$ for $2 \mathrm{~min}$ and stored on ice. Total RNAs from different tissues and different stages were mixed together for the subsequent purification. The mRNA was purified via the poly A tail using the NucleoTrap mRNA kit (Clontech, CA, USA) according to the manufacturer's instructions. After washing with $200 \mu \mathrm{L}$ of washing buffer twice, 10 20 $\mu \mathrm{L} 10 \mathrm{mM}$ Tris- $\mathrm{HCl}$ (pH 
7.5) was added to elute the mRNA at $80^{\circ} \mathrm{C}$ for $2 \mathrm{~min}$. The first-strand cDNA was synthesized using the SMART III reverse-transcriptase kit (Takara, Dalian, China). The reverse-transcriptase reaction was terminated at $75^{\circ} \mathrm{C}$ for $10 \mathrm{~min}$, after which $1 \mu \mathrm{L}$ RNase $\mathrm{H}(2$ Units) was added and incubated at $37^{\circ} \mathrm{C}$ for $20 \mathrm{~min}$ to digest the redundant mRNA.

\section{The synthesis of double-strand CDNA using LD-PCR, purification and normalization}

The double-strand cDNA was synthesized using longdistance (LD)-PCR containing $2 \mu \mathrm{L}$ of first-strand cDNA, $10 \mu \mathrm{L} 10 \times$ Advantage 2 PCR buffer, $2 \mu \mathrm{L} 50 \times \mathrm{dNTP}$ Mix, $2 \mu \mathrm{L} 5^{\prime}$ PCR primer, $2 \mu \mathrm{L}$ 3' $\mathrm{PCR}$ primer, $10 \mu \mathrm{L}$ melting solution, $2 \mu \mathrm{L} 50 \times$ Advantage 2 polymerase mix (Clontech, CA, USA), and $\mathrm{ddH}_{2} \mathrm{O}$ up to a volume of $100 \mu \mathrm{L}$. The PCR temperature program encompassed an initial denaturation step at $95^{\circ} \mathrm{C}$ for $30 \mathrm{~s}$, followed by $20 \mathrm{cy}$ cles of $95^{\circ} \mathrm{C}, 10 \mathrm{~s}, 65^{\circ} \mathrm{C}, 6 \mathrm{~min}$ (each cycle increased by $5 \mathrm{~s}$ ), and a final elongation step at $68^{\circ} \mathrm{C}$ for $6 \mathrm{~min}$. Following detection via agarose gel electrophoresis, the rest of the double-strand cDNA was added into the CHROMA SPIN TE-400 column (Takara, Dalian, China) for purification. The purified cDNA was precipitated with $1 / 10$ volume of $3 \mathrm{M} \mathrm{NaAc}$ and 2.5 volumes of ethanol, and then stored at $-20^{\circ} \mathrm{C}$ for $1 \mathrm{~h}$. The precipitate was resuspended in $20 \mu \mathrm{L}$ $\mathrm{dd}_{2} \mathrm{O}$ and examined via agarose electrophoresis. The double-strand cDNA was normalized using the TrimmerDirect cDNA normalization kit (Evrogen, Moscow, Russia). The $4 \mu \mathrm{L} 4 \times$ hybridizaiton buffer was added into the cDNA and incubated at $98^{\circ} \mathrm{C}$ for $2 \mathrm{~min}$ and then at $68^{\circ} \mathrm{C}$ for $5 \mathrm{~h}$. Then, $4 \mu \mathrm{L}$ of $4 \times \mathrm{DSN}$ buffer and $0.2 \mu \mathrm{L}$ duplexspecific nuclease (DSN) $(1 \mathrm{U} / \mu \mathrm{L})$ were added into the PCR tube and incubated at $68^{\circ} \mathrm{C}$ for $3 \mathrm{~min}$. The normalized product was extracted with phenol and chloroform once and finally diluted in $20 \mu \mathrm{L}$ DEPC $\mathrm{ddH}_{2} \mathrm{O}$.

\section{Ligation of double-stranded cDNA with library vectors to construct the three-frame library}

The normalized cDNA was divided into triplicates and ligated with linearized pGADT7-SmaI-1, pGADT7SmaI-2, and pGADT7-SmaI- 3 vectors, respectively, by homologous recombination. The ligation system contained $7 \mu \mathrm{L}$ cDNA, $3 \mu \mathrm{L}$ library vector DNA, $5 \mu \mathrm{L}$ InFusion recombinase (Clontech, CA, USA), and $\mathrm{dd}_{2} \mathrm{O}$ up to $20 \mu \mathrm{L}$, and was incubated at $50^{\circ} \mathrm{C}$ for $1 \mathrm{~h}$. The ligation reaction was terminated by adding $2 \mu \mathrm{L}$ proteinase K (Sigma-Aldrich, USA), followed by the addition of $1 \mu \mathrm{L} 20 \mu \mathrm{g} / \mu \mathrm{L}$ glycogen (Sigma-Aldrich), $50 \mu \mathrm{L} 7.5 \mathrm{M}$ $\mathrm{NH}_{4} \mathrm{Ac}$, and $375 \mu \mathrm{L}$ ethanol, and stored at $-80^{\circ} \mathrm{C}$ for at least $1 \mathrm{~h}$. The ligation product was condensed and resuspended in $10 \mu \mathrm{L}$ DEPC $\mathrm{ddH}_{2} \mathrm{O}$ on ice.
Electroporation of the recombinant libraries into E. coli DH10B and S. cerevisiae Y187

The $1 \mathrm{~mm}$ electroporation cuvettes were precooled on ice for $30 \mathrm{~min}$, after which $2.5 \mu \mathrm{L}$ recombinant vector DNA and $50 \mu \mathrm{L}$ competent cells of $E$. coli DH10B were mixed in the cuvettes and electroporated at $2000 \mathrm{~V}$ for $5 \mathrm{~ms}$. After that, $1 \mathrm{~mL}$ of LB medium was rapidly added into the cuvette. The transformed bacteria were gently mixed with liquid $\mathrm{LB}$ and the medium volume increased to $5 \mathrm{~mL}$, followed by incubation at $37^{\circ} \mathrm{C}$ for $1 \mathrm{~h}$. The cultured bacteria were diluted 10-, 100-, 1000-, 10,000and 100,000-fold and spread on LB agar plates with ampicillin (Sigma-Aldrich). The rest of the bacteria were stored at $-80{ }^{\circ} \mathrm{C}$. The plasmid library was extracted using a plasmid-purification kit (Qiagen, Valencia, CA) and then used to transform S. cerevisiae Y187 to construct the yeast library following the same electroporation method described, but with YPDA instead of LB.

\section{Determination of the library capacity and the average length of the inserted fragments}

A sample comprising $10 \mu \mathrm{L}$ of 100,000 -fold diluted bacteria was used for plate counting. The library capacity was calculated according to the formula $\mathrm{CFU} / \mathrm{mL}=\mathrm{col}-$ onies on the plate/ $10 \mu \mathrm{L} \times 100,000 \times 1 \times 10^{3}$. The total $\mathrm{CFU}$ of the library $=\mathrm{CFU} / \mathrm{mL} \times$ total volume of library $(50 \mathrm{~mL})$. A total of 20 randomly selected colonies were picked to amplify the inserted fragments of the library. The amplification primers were designed based on the pGADT7-Rec vector (T7-F: 5'-GGAGTACCCATACG ACGTACC-3' and T7-R: 5'-TATCTACGATTCAT CTGCAGC-3'), compared with pGADT7-T vector as positive control and $\mathrm{ddH}_{2} \mathrm{O}$ as negative control. The lengths of the inserted fragments were analyzed via agarose gel electrophoresis. Eight out of 19 positive colonies were sequenced at Sangon Biotech (Shanghai, China). The sequencing results were blasted in the National Center for Biotechnology Information (NCBI) database to identify their resources and closely related functions in other species. The similar calculation method was applied to count library capacity of yeast except that the yeast cells were from $10 \mu \mathrm{L}$ liquid of 1000-fold diluted.

The auto-activation and toxicity detection of bait vectors In order to identify the methyl jasmonate signaling pathway in C. faberi, a candidate gene, CfbHLH36, selected based on RNA-seq results were cloned and inserted into bait vector of pGBKT7 with NdeI and SalI restriction sites. The ligation products of pGBKT7CfbHLH36 were transformed into E. coli $\mathrm{DH} 5 \alpha$ and the positive recombinant colonies were selected to extract plasmids. Following the identification and sequencing of the recombinant plasmids, about $100 \mathrm{ng}$ recombinant plasmid of pGBKT7-CfbHLH36 and $100 \mathrm{ng}$ prey vector 
plasmid of pGADT7 were co-transformed into competent cells of $\mathrm{Y} 2 \mathrm{H}$ Gold yeast to detect the autoactivation and toxicity. The transformed competent cells were then cultured into media of SD/-Leu/-Trp (DDO), SD/-Leu/Trp/-His (TDO) and SD/-Leu/-Trp/-His plates with 5 $\mathrm{mM}, 10 \mathrm{mM}, 15 \mathrm{mM}$ and $20 \mathrm{mM} \mathrm{3}$ ' AT, respectively at $30{ }^{\circ} \mathrm{C}$ for $3-4$ days. The diameters and colors of colonies were observed and recorded.

\section{The screening and identification of positive interactors in $\mathrm{Y} 2 \mathrm{H}$ library}

The fresh colony of bait vector pGBKT7-CfbHLH36 was selected and cultured in $50 \mathrm{~mL} \mathrm{SD} /-\operatorname{Trp}$ media at $30^{\circ} \mathrm{C}$, $250 \mathrm{rpm}$ until the $\mathrm{OD}_{600}$ reach to 0.8 . Then the $\mathrm{Y} 2 \mathrm{H}$ Gold yeast cells were collected and resuspended in $5 \mathrm{~mL}$ $\mathrm{SD} /$-Trp media, which was prepared for the mating with $1 \mathrm{~mL}$ cDNA library in $45 \mathrm{~mL} 2 \times$ YPDA media at $30^{\circ} \mathrm{C}$, $50 \mathrm{rpm}$ for $20 \mathrm{~h}$. The growth of the zygotes was observed and recorded with inverted microscope (XDS-1A, Shanghai Precision Instrument Co., Shanghai, China). Compared with the growth condition of positive and negative controls, the yeast zygotes were collected and cultured on $50 \mathrm{SD} /$-Leu/-Trp/-His/X- $\alpha$-Gal plates (TDO/X) with 10 $\mathrm{mM} 3{ }^{\prime} \mathrm{AT}$ at $30^{\circ} \mathrm{C}$ for $3-5 \mathrm{~d}$. The candidate blue yeast cells were selected and transferred into stringent $\mathrm{SD} /$-Leu/Trp/-His/-Ade/X- $\alpha$-Gal plates (QDO/X) with $10 \mathrm{mM}$ $3^{\prime} \mathrm{AT}$ at $30^{\circ} \mathrm{C}$ for $3 \mathrm{~d}$ to increase the selection pressure, compared with pGBKT7-53 and pGADT7-T cotransformed as positive control, pGBKT7-Lam and pGADT7-T co-transformed as negative control. Finally, about 50 blue colonies were randomly selected, cultured in SD/-Leu/-Trp/-His/-Ade liquid media (QDO) and identified with PCR and sequencing, compared with pGADT7-T vector as positive control. All of the reagents used in yeast culture and library screening were bought from Clontech company (CA, USA). All of the restriction digestion enzymes were bought from Takara Company (Dalian, China). The PCR products were sequenced at Sangon Biotech Company (Shanghai, China).

\section{Supplementary information}

Supplementary information accompanies this paper at https://doi.org/10. 1186/s12896-020-0599-2.

Additional file 1. The sequencing and blast results of the randomly selected eight colonies in library construction.

Additional file $\mathbf{2}$. The sequencing and blast results of the 20 selected positive colonies in library screening.

\section{Abbreviations}

3'AT: 3-Aminotriazole; CFU: Colony-forming units; DDO: SD/-Leu/-Trp; DEPC: Diethyl pyrocarbonate; DSN: Duplex-specific nuclease; LD-PCR: Long distance-PCR; QDO: SD/-Leu/-Trp/-His/-Ade; TDO: SD/-Leu/-Trp/-His; TF: Transcription factor; $\mathrm{Y} 1 \mathrm{H}$ : Yeast one-hybrid; $\mathrm{Y} 2 \mathrm{H}$ : Yeast two-hybrid

\section{Acknowledgements}

We are thankful to Wuhan Genecreate Bioengineering Co., Ltd. for kindly technical support.

\section{Authors' contributions}

$Y Z$ designed and conducted the experiments, analyzed the data and wrote the manuscript. YX, JZ and QL conducted the experiments. $\mathrm{KL}$ analyzed the data and provided the technical support. All authors read and approved the final manuscript.

\section{Funding}

This work was supported by the National Natural Science Foundation of China (Grant No. 31700626) and the Scientific Research Foundation for the First-class Discipline of Chinese Medicine Program of Jiangxi University of Traditional Chinese Medicine (JXSYLXK-ZHYAO023). These funding bodies did not play any role in the design, execution, analysis, and interpretations of data or in writing the manuscript.

\section{Availability of data and materials}

The cDNA library of Cymbidium faberi in this study can be available to researchers upon reasonable request to the corresponding author.

Ethics approval and consent to participate

Not applicable.

\section{Consent for publication}

Not applicable.

\section{Competing interests}

The authors declare that they have no competing interests.

\section{Author details}

${ }^{1}$ College of Pharmacy, Jiangxi University of Traditional Chinese Medicine, Nanchang 330006, People's Republic of China. ${ }^{2}$ Center of Applied Biotechnology, Wuhan University of Bioengineering, Wuhan 430415, People's Republic of China. ${ }^{3}$ College of Bioscience and Biotechnology, Wuhan University of Bioengineering, Wuhan 430415, People's Republic of China. ${ }^{4}$ Department of Protein Services, Wuhan Genecreate Bioengineering Co., Ltd, Wuhan 430206, People's Republic of China.

Received: 22 October 2019 Accepted: 3 January 2020

Published online: 16 January 2020

\section{References}

1. Sun Y, Li Y, Huang G, Wu Q, Wang L. Application of the yeast one-hybrid technique to plant functional genomics studies. Biotechnol Biotechnol Equip. 2017:31(6):1087-92.

2. Ji X, Wang L, Zang D, Wang Y. Transcription factor-centered yeast onehybrid assay. Methods Mol Biol. 1794;11(2018):183-94.

3. Jiang W, Liu T, Nan W, Jeewani DC, Niu Y, Li C, Wang Y, Shi X, Wang C, Wang J, Li Y, Gao X, Wang Z. Two transcription factors TaPpm1 and TaPpb1 co-regulate anthocyanin biosynthesis in purple pericarps of wheat. J Exp Bot. 2018;69(10):2555-67.

4. Lopato S, Bazanova N, Morran S, Milligan AS, Shirley N, Langridge P. Isolation of plant transcription factors using a modified yeast one-hybrid system. Plant Methods. 2006;2:3.

5. Mitsuda N, Ikeda M, Takada S, Takiguchi Y, Kondou Y, Yoshizumi T, Fujita M, Shinozaki K, Matsui M, Ohme-Takagi M. Efficient yeast one-/two-hybrid screening using a library composed only of transcription factors in Arabidopsis thaliana. Plant Cell Physiol. 2010;51(12):2145-51.

6. Zhan Y, Sun X, Rong G, Hou C, Huang Y, Jiang D, Weng X. Identification of two transcription factors activating the expression of OsXIP in rice defense response. BMC Biotechnol. 2017:17:26

7. Petzold HE, Rigoulot SB, Zhao C, Chanda B, Sheng X, Zhao M, Jia X, Dickerman AW, Beers EP, Brunner AM. Identification of new protein- protein and protein- DNA interactions linked with wood formation in Populustrichocarpa. Tree Physiol. 2017:38:362-77.

8. Dharmaraj K, Cui W, EHA R, Templeton MD. Construction of a kiwifruit yeast two-hybrid CDNA library to identify host targets of the Pseudomonas syringae pv. actinidiae effector AvrPto5. BMC Res Notes. 2019;12(1):63. 
9. Sánchez-Montesino R, Oñate-Sánchez L. Yeast one- and two-hybrid highthroughput screenings using arrayed libraries. Methods Mol Biol. 1629; 5(2017):47-65.

10. Matiolli CC, Melotto M. A comprehensive Arabidopsis yeast two-hybrid library for protein-protein interaction studies: a resource to the plant research community. Mol Plant-Microbe Interact. 2018;31(9):899-902.

11. Xu Q, Wang S, Hong H, Zhou Y. Transcriptomic profiling of the flower scent biosynthesis pathway of Cymbidium faberi Rolfe and functional characterization of its jasmonic acid carboxyl methyltransferase gene. BMC Genomics. 2019;20:125.

12. Huang M, Ma C, Yu R, Mu L, Hou J, Yu Y, Fan Y. Concurrent changes in methyl jasmonate emission and the expression of its biosynthesis-related genes in Cymbidium ensifolium flowers. Physiol Plantarum. 2015;153:503-12.

13. Zhou Y, Chen L, Xu Y, Wang Y, Wang S, Ge X. The CfAOS and CfAOC genes related to flower fragrance biosynthesis in Cymbidium faberi could confer drought tolerance to transgenic tomatoes. Int J Agric Biol. 2018;20(4):883-92.

14. Seo HS, Song JT, Cheong JJ, Lee YH, Lee YW, Hwang I, Lee JS, Choi YD. Jasmonic acid carboxyl methyltransferase: a key enzyme for jasmonateregulated plant responses. Proc Natl Acad Sci U S A. 2001;98:4788-93.

15. Sasaki-Sekimoto Y, Saito H, Masuda S, Shirasu K, Ohta H. Comprehensive analysis of protein interactions between JAZ proteins and bHLH transcription factors that negatively regulate jasmonate signaling. Plant Signal Behav. 2014;9:e27639.

16. Nakata M, Mitsuda N, Herbe M, Koo AJK, Moreno JE, Suzuki K, Howe GA, Ohme-Takagi M. A bHLH-type transcription factor, ABA-INDUCIBLE BHLHTYPE TRANSCRIPTION FACTOR/JA-ASSOCIATED MYC2-LIKE1, acts as a repressor to negatively regulate jasmonate signaling in Arabidopsis. Plant Cell. 2013;25:1641-56.

17. Pedersen T, Skjesol A, Jorgensen JB. VP3, a structural protein of infectious pancreatic necrosis virus, interacts with RNA-dependent RNA polymerase VP1 and with double-stranded RNA. J Virol. 2007;81(12):6652-63.

18. Stellberger T, Hauser R, Baiker A, Pothineni VR, Haas J, Uetz P. Improving the yeast two-hybrid system with permutated fusions proteins: the Varicella Zoster virus interactome. Proteome Sci. 2010;8:8.

19. Yu D, Liao L, Zhang J, Zhang Y, Xu K, Liu K, Li X, Tan G, Chen R, Wang Y, Liu $X$, Zhang X, Han X, Wei Z, Li C. A novel, easy and rapid method for constructing yeast two-hybrid vectors using in-fusion technology. Biotechniques. 2018:64(5):219-24.

20. Yachie N, Petsalaki E, Mellor JC, Weile J, Jacob Y, Verby M, Ozturk SB, Li S, Cote AG, Mosca R, Knapp JJ, Ko M, Yu A, Gebbia M, Sahni N, Yi S, Tyagi T, Sheykhkarimli D, Roth JF, Wong C, Musa L, Snider J, Liu YC, Yu H, Braun P, Stagljar I, Hao T, Calderwood MA, Pelletier L, Aloy P, Hill DE, Vidal M, Roth FP. Pooled-matrix protein interaction screens using barcode fusion genetics. Mol Syst Biol. 2016;12(4):863.

21. Trigg SA, Garza RM, Macwilliams A, Nery JR, Bartlett A, Castanon R, Goubil A, Feeney J, O'Malley R, Huang SC. CrY2H-seq: a massively multiplexed assay for deep-coverage interactome mapping. Nat Methods. 2017;14(8):819-25.

22. Yang F, Lei Y, Zhou M, Yao Q, Han Y, Wu X, Zhong W, Zhu C, Xu W, Tao R, Chen X, Lin D, Rahman K, Tyagi R, Habib Z, Xiao S, Wang D, Yu Y, Chen H, Fu Z, Cao G. Development and application of a recombination- based library versus library high-throughput yeast two-hybrid (RLL-Y2H) screening system. Nucl Acid Res. 2018;46(3):e17.

23. Ohara O, Temple G. Directional cDNA library construction assisted by the in vitro recombination reaction. Nucl Acid Res. 2001;29(4):e22.

24. Yang M, Zhao Y, Ma P. Construction of yeast two-hybrid library of Salvia miltiorrhiza and screening of SmJAZ8 interaction protein. China J Chinese Mater Med. 2018:43(3):484-92.

25. Xing Q, Yan J, Zhang W, Liu M, Fu C, Li X. Construction of a yeast two hybrid cDNA library from tobacco leaves infected by Lasiodiplodia theobromae. Acta Phytopathol Sinica. 2017;47(5):716-20.

26. Yang $H$, Zhou $Y$, Zhang $Y$, Wang J, Shi $H$. Identification of transcription factors of nitrate reductase gene promoters and NRE2 cis-element through yeast one-hybrid screening in Nicotiana tabacum. BMC Plant Biol. 2019; 19(1):145.

27. Major IT, Yoshida Y, Campos ML, Kapali G, Xin XF, Sugimoto K, de Oliveira FD, He SY, Howe GA. Regulation of growth-defense balance by the JASMONATE ZIM-DOMAIN (JAZ)-MYC transcriptional module. New Phytol. 2017;215(4):1533-47

28. Zhang F, Yao J, Ke J, Zhang L, Lam VQ, Xin X, Zhou X, Chen J, Brunzelle J, Griffin PR, Zhou M, Xu HE, Melcher K, He SY. Structural basis of JAZ repression of MYC transcription factors in jasmonate signaling. Nature. 2015; 525(7568):269-73.

29. Du M, Zhao J, Tzeng DTW, Liu Y, Deng L, Yang T, Zhai Q, Wu F, Huang Z, Zhou M, Wang Q, Chen Q, Zhong S, Li CB, Li C. MYC2 orchestrates a hierarchical transcriptional cascade that regulates jasmonate-mediated plant immunity in tomato. Plant Cell. 2017;29(8):1883-906.

\section{Publisher's Note}

Springer Nature remains neutral with regard to jurisdictional claims in published maps and institutional affiliations.
Ready to submit your research? Choose BMC and benefit from:

- fast, convenient online submission

- thorough peer review by experienced researchers in your field

- rapid publication on acceptance

- support for research data, including large and complex data types

- gold Open Access which fosters wider collaboration and increased citations

- maximum visibility for your research: over $100 \mathrm{M}$ website views per year

At BMC, research is always in progress.

Learn more biomedcentral.com/submissions 